\title{
Antibodies to Histones in Drug-Induced and Idiopathic Lupus Erythematosus
}

\author{
M. J. FrITZLER and E. M. TAN, Division of Rheumatic Diseases, University of Colorado \\ Medical Center, Denver, Colorado 80262
}

\begin{abstract}
A BSTRACT When tissue sections are extracted with $0.1 \mathrm{~N} \mathrm{HCl}$, cellular nuclear proteins, including histones, are removed but nuclear DNA is retained. Histones can be reconstituted back to nuclear DNA in acid-extracted tissue sections so that the resulting nuclear substrate is composed only of DNA and histones and does not contain acidic nuclear protein antigens. The resulting DNA-histone tissue substrate can be used in the immunofluorescent method for specific detention of antibodies to histones. Sera from 23 patients with drug-induced lupus erythematosus (procainamide 19, isoniazid 2, nitrofurantoin 2) and 20 patients with idiopathic (not drug-induced) systemic lupus erythematosus (SLE) were studied. All 23 patients with drug-induced lupus erythematosus (LE) lost nuclear staining on acid-extracted sections. In contrast, only 12 of 20 with idiopathic SLE lost nuclear staining on acid-extracted tissues, and in the remaining 8 , there was no significant fall in titer. In the drug-induced LE group, loss of nuclear staining was due to the absence of histones on the substrate because with histone-reconstituted sections, 22 of 23 again became positive for nuclear staining at titers equal to or at one doubling dilution below titers on unextracted tissues. In contrast, of the 12 idiopathic SLE sera which lost nuclear staining, only 5 regained nuclear staining on histone-reconstituted tissue sections. In idiopathic SLE, antinuclear antibodies are heterogeneous in specificities and may consist of antibodies to native DNA, histones, or nonhistone proteins. In contrast, antinuclear antibodies in druginduced LE are less heterogeneous and mainly consist of antibodies to histones.
\end{abstract}

\section{INTRODUCTION}

The observation that antibodies to histones can be demonstrated on mouse kidney sections (1) has

Dr. Fritzler is a fellow of the Medical Research Council of Canada.

Received for publication 2 February 1978 and in revised form 22 March 1978. prompted further analysis of idiopathic and druginduced lupus erythematosus (LE) ${ }^{1}$ sera. Antibodies to histones in systemic lupus erythematosus (SLE) sera have been previously described $(2,3)$ but they were shown to occur infrequently and to be present in relatively low titers. This may have been partly due to the fact that complement fixation was used by previous investigators and, because histones themselves are anticomplementary (4), the assay system may only have allowed detection of sera with relatively high concentration of antibodies. In contrast, antibodies specific for deoxyribonucleoprotein (DNP), which is a complex of DNA and histones, have been shown to be present in a high percentage of patients with either idiopathic or drug-induced $\operatorname{LE}(5,6)$. Studies to define the mechanism of the interaction between DNP and antibody demonstrated that neither the DNA nor the bimolecular complex of DNA and histone was reactive by itself with the antibody $(5,6)$. These observations led to the postulate that the integrity of the bimolecular complex of DNA and histone was essential to the antigenicity of DNP. An extension of this concept was that histone was the important antigenic determinant, and that complexing with DNA was essential for "revealing" the antigenic site on histone (7).

Drug-induced LE presented unusual opportunities to study mechanisms which controlled production of autoantibodies, because in this instance, the autoantibody production could be clearly related to drug intake. In hydralazine-induced LE, it was shown that development of antinuclear antibodies was related to the enzyme activity of $\mathrm{N}$-acetyltransferase in the patient. "Slow" acetylators developed autoantibodies and symptomatic disease earlier and after lower total drug

\footnotetext{
'Abbreviations used in this paper: ANA, antinuclear antibody; DNP, deoxyribonucleoprotein; dsDNA, doublestranded DNA; H1, H2A, H2B, H3, H4, Ciba Foundation Symposium nomenclature of histone (volume 28); LE, lupus erythematosus, PBS, phosphate-buffered saline; SLE, systemic lupus erythematosus.
} 
intake than "rapid" acetylators (8). A similar phenomenon has recently been observed in patients treated with procainamide (9), suggesting a common mechanism for induction of LE-like disease by certain drugs. This mechanism should involve, at least in part, acetylation of ingested drug by $\mathrm{N}$-acetyltransferase. Further study with hydralazine has shown that this drug is able to form complexes with DNP (7). Antigenicity of native DNP was destroyed by either DNase or trypsin treatment but, in contrast, hydralazine-DNP antigenicity could be destroyed by DNase, but not by trypsin. This observation suggested that hydralazine complexes to the histone moiety of DNP, thereby interfering in some manner with enzymatic breakdown of histone protein. These were some of the considerations which stimulated the current study concerning antibodies to histone in drug-induced LE and idiopathic SLE.

The preparation and purification of histones has depended upon their acid extraction from chromatin (10) although salt extraction has been known to be an equally useful technique (11). Experimental evidence suggests that irreversible conformational changes occur after acid extraction (12), making interpretation of in vitro histone chemistry difficult. Salt-extracted histones may not undergo such irreversible changes, and, in fact, recent evidence shows that such histone preparations contain antigenic determinants different from acid-extracted histones (13). This evidence also led to our renewed interest in histones and their relation to connective tissue diseases, because many of the previous studies on antibodies to histones were performed with acid-extracted histones.

We present the results of studies concerning the immunochemical specificities of antinuclear antibodies in drug-induced LE and in idiopathic SLE in this paper. It was shown that certain antibodies in both diseases reacted in immunofluorescence with an elutable component of tissue nuclei. These antibodies became nonreactive when tissues were extracted under conditions which removed nuclear histone. Restoration of positive immunofluorescence after incubation of extracted tissues with purified calf thymus histone confirmed that the specificity of these antibodies was against histones. The majority of these antibodies were against histones H2A-H2B. In druginduced LE, anti-histone antibodies constituted the major type of antinuclear antibody, whereas, in idiopathic LE, many other specificities of antinuclear antibodies were present.

\section{METHODS}

Sera. Sera from patients with idiopathic and drug-induced (procainamide 19, isoniazid 2, nitrofurantoin 2) LE which were used for this study had positive antinuclear antibody (ANA) as determined by indirect immunofluorescence. We have used the term idiopathic SLE to distinguish the group of patients who developed the disease spontaneously in contrast to the patients who developed LE after the ingestion of drugs. Patients with idiopathic SLE were diagnosed on the basis of at least four of the ARA preliminary criteria (14) for that disease. Sera from 20 patients were taken from our SLE serum bank. 6 of the 20 patients had biopsy-proven glomerulonephritis. Two additional patients had proteinuria of $>1 \mathrm{~g} /$ day but no kidney biopsy had been performed. The other 12 patients did not have evidence of clinical renal disease. The sera were known to be positive for ANA by indirect immunofluorescence but no further selection was made concerning content of antibodies to DNA, nucleoprotein, or other nuclear antigens.

The patients with drug-induced LE had no history of connective tissue disease before the onset of myalgia, fever, pleuropulmonic involvement, arthralgias, or arthritis which were temporally associated with the administration of a therapeutic drug. These were all patients who had been treated for several months to years and were being evaluated for rheumatic complaints. These patients did not have overt renal disease, an additional feature which was used to differentiate them from idiopathic LE.

All sera were heated for $30 \mathrm{~min}$ at $56^{\circ} \mathrm{C}$ to inactivate complement and antibody profiles assessed by immunodiffusion in agarose against saline-soluble antigens $(\mathrm{Sm}$, ribonucleoprotein, and Sjögren's syndrome antigen B) extracted from rabbit thymus in accordance with procedures published previously $(15,16)$. Antibodies to double- and single-stranded DNA were measured by the Millipore filter technique (Millipore Corp., Bedford, Mass) $(17,18)$. The latter consisted of the use of tritium-labeled Bacillus subtilis DNA which had been sonically disrupted. Control specimens with antibody to native DNA (from a SLE serum) and to singlestranded DNA (from a rabbit immunized with denatured DNA) were always included with every assay (18).

Immunofluorescent antibody technique. The indirect immunofluorescent antibody technique used $4-\mu \mathrm{m}$ mouse kidney sections as previously described (19). The sections were fixed for $10 \mathrm{~min}$ at room temperature in acetone, and then air dried for $10 \mathrm{~min}$. Fluorescein-conjugated antiserum was prepared (20) from goats immunized against human IgG purified by DEAE chromatography.

Acid elution and histone reconstitution were performed using freshly cut, acetone-fixed mouse kidney sections (1). It was observed that the extraction of nuclear proteins could be performed equally well with $0.1 \mathrm{~N} \mathrm{HCl}, 2.0 \mathrm{M} \mathrm{NaCl}$, or $4.0 \mathrm{M}$ urea. However, extensive washing of $\mathrm{NaCl}-$ or urea-extracted tissue was required before it could be used for indirect immunofluorescence histone reconstitution. Therefore, because no advantage to the salt or urea extraction of mouse kidney sections could be demonstrated, extraction with $0.1 \mathrm{~N} \mathrm{HCl}$ was used for all experiments described here. The mounted kidney sections were immersed in $0.1 \mathrm{~N}$ $\mathrm{HCl}$ and gently agitated for $30 \mathrm{~min}$ at room temperature. After rinsing in two changes of phosphate-buffered saline (PBS) $(0.15 \mathrm{M} \mathrm{NaCl}$; $0.01 \mathrm{M}$ phosphate buffer, pH 7.3), the sections were ready for use as substrates representing protein-extracted tissue sections or for reconstitution with histones.

Lyophilized, salt-extracted calf thymus histone prepared as described below, was freshly dissolved in PBS at a final concentration of $25 \mu \mathrm{g} / \mathrm{ml}$. The extracted kidney sections were immersed in the histone solution for $30 \mathrm{~min}$ at room temperature, rinsed in two changes of PBS, and used as substrates in immunofluorescence. As in a previous study (1), the optimal histone concentration was found to be between 15 and $25 \mu \mathrm{g} / \mathrm{ml}$. 


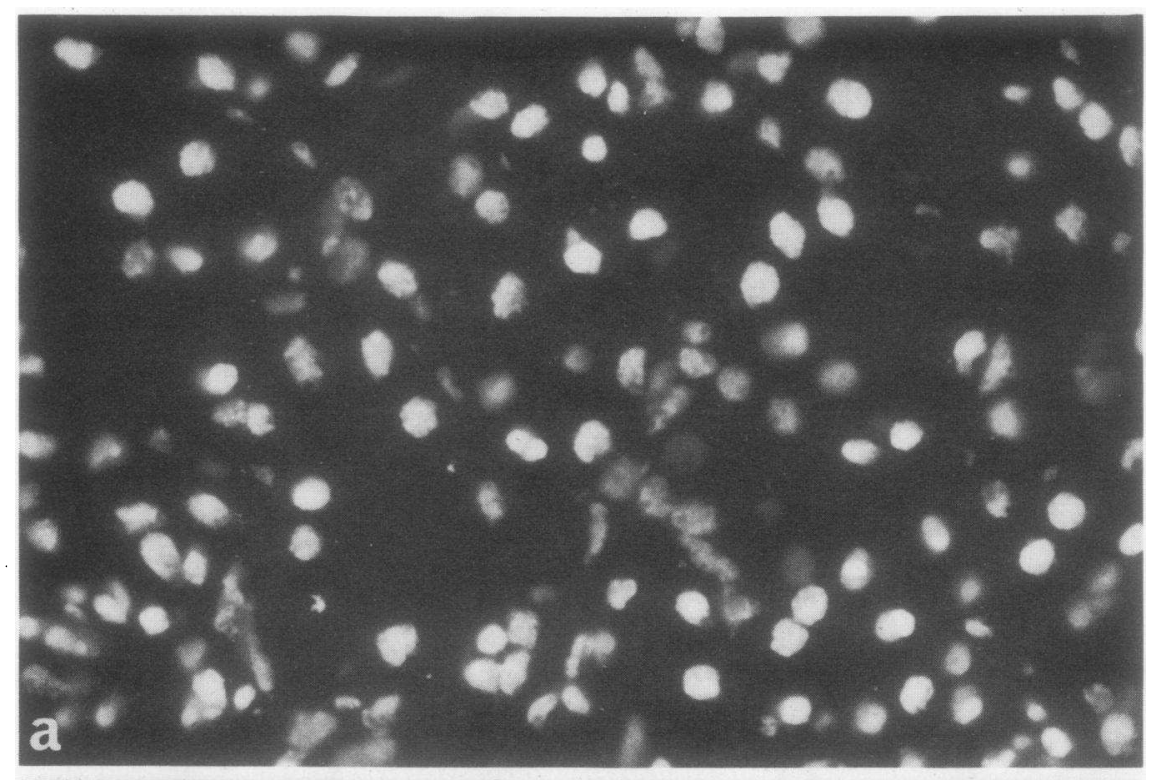

b

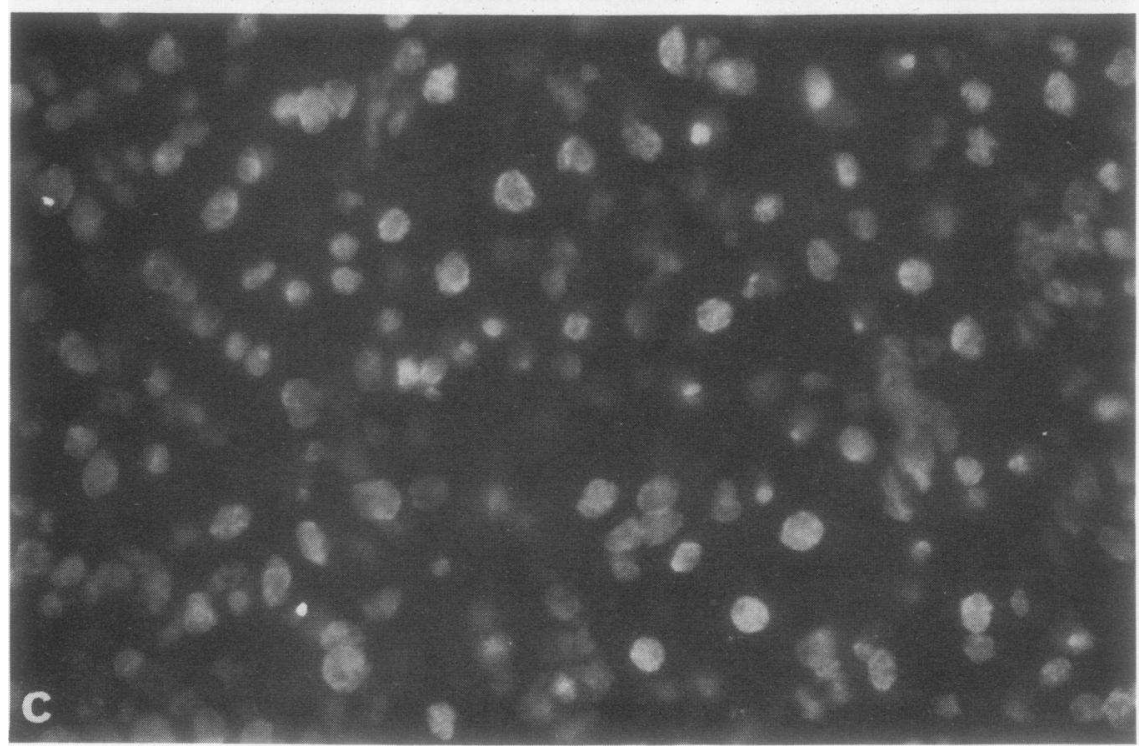


Histochemistry. Histones were also demonstrated histochemically by the alkaline fast green technique developed by others (21). The staining reaction consisted of a 15-min incubation of cryostat-sectioned mouse kidney slides in a $5 \%$ (wt/vol) solution of trichloroacetic acid in a boiling water bath followed by three washes in $70 \%$ ethanol. After rinsing in distilled water, the slides were stained for $30 \mathrm{~min}$ at room temperature in a $0.1 \%$ solution of fast green FCF (Matheson, Coleman, \& Bell, East Rutherford, N. J.) in distilled water adjusted to $\mathrm{pH} 8.0$ with $\mathrm{NaOH}$. The sections were washed in distilled water, then in $95 \%$ ethanol, and mounted after dehydration and clearing in xylene. This technique has been shown to stain all classes of histone (21).

Acridine orange staining of the mouse kidney sections was performed using the procedure of Bertalanffy and Bickis (22). A $0.01 \%$ solution of acridine orange ( $K \& \mathrm{~K}$ Laboratories Inc., Plainview, N. Y.) in PBS, pH 6.3 was used for staining at room temperature for $15 \mathrm{~min}$. The sections were then rinsed in PBS, differentiated in $0.1 \mathrm{M} \mathrm{CaCl}_{2}$ for $30 \mathrm{sec}$, rinsed again in PBS, and mounted in 50\% glycerol. The acridine orange slides were viewed in a Leitz Ortholux microscope fitted for epifluorescence with a BG 12 excitor filter and a 490-nm barrier filter.

Preparation of chromatin and extraction of histones. Frozen saline-washed calf thymus was purchased from Pel Freez Farms, Inc., Rogers, Ark. Nuclei and chromatin were prepared (23) by thawing $30 \mathrm{~g}$ of calf thymus, freed of fat and connective tissue, at $4^{\circ} \mathrm{C}$ in $300 \mathrm{ml}$ of homogenizing media (0.25 M sucrose; $10 \mathrm{mM} \mathrm{MgCl}_{2} ; 10 \mathrm{mM}$ Tris- $\mathrm{HCl}, \mathrm{pH} 8.0$; and $50 \mathrm{~nm} \mathrm{NaHSO}$ added as crystals just before use). The tissue was finely minced and homogenized in a total volume of $600 \mathrm{ml}$ with a Waring blender (Waring Products Div., Dynamics Corp of America, New Hartford, Conn.) set at 30 $\mathrm{V}$ for $1 \mathrm{~min}$ and at $60 \mathrm{~V}$ for the next minute. The homogenate was filtered through four layers of cheesecloth and centrifuged at $500 \mathrm{~g}$ for $10 \mathrm{~min}$. The supernate was discarded and the pellet was mixed for $3 \mathrm{~min}$ in washing media (homogenizing media plus $0.5 \%$ [wt/vol] Triton-X, Rohm \& Haas Co., Philadelphia, Pa.) using the Waring blender set at $20 \mathrm{~V}$. The nuclei were pelleted again at $500 \mathrm{~g}$ for $10 \mathrm{~min}$, resuspended in $300 \mathrm{ml}$ of washing media, remixed as above, and pelleted. The nuclear pellet was resuspended in homogenizing media and pelleted through $1.62 \mathrm{M}$ sucrose at $63,000 \mathrm{~g}$ for $1 \mathrm{~h}$. The purified nuclear pellet was washed in homogenizing media and finally pelleted at $5,000 \mathrm{~g}$ for $10 \mathrm{~min}$.

Purified chromatin was prepared by freeze-thawing two 30-g nuclear pellets followed by disruption in a Dounce homogenizer (Kontes Co., Vineland, N. J.) in $20 \mathrm{mM}$ EDTA; $10 \mathrm{mM}$ Tris- $\mathrm{HCl}, \mathrm{pH} 8.0$ and $50 \mathrm{mM} \mathrm{NaHSO}$. Histone 1 (Hl) was extracted from this amount of chromatin with 300 $\mathrm{ml}$ of $600 \mathrm{mM} \mathrm{NaCl} ; 50 \mathrm{mM} \mathrm{Na}$ acetate buffer, pH 5.0. The DNP was sedimented for $36 \mathrm{~h}$ at at $2-4^{\circ} \mathrm{C}$ in polyallomer tubes at $100,000 \mathrm{~g}$. Other histones (H2A, H2B, H3, and H4) were extracted from the DNP with $2.0 \mathrm{M} \mathrm{NaCl}$ in the 50 $\mathrm{mM} \mathrm{Na}$ acetate buffer and the extracted DNA sedimented as above. The pellet was reextracted with buffered $2.0 \mathrm{M}$ $\mathrm{NaCl}$ and the DNA pelleted.

The supernates containing the histones were concentrated by ultrafiltration (Millipore Corp._-immersible molecular separator kit), desalted by dialysis against distilled water, lyophilized, and stored dessicated at $-20^{\circ} \mathrm{C}$. All procedures were carried out at $4^{\circ} \mathrm{C}$ and all solutions contained $50 \mathrm{mM}$ $\mathrm{NaHSO}_{3}$ as protease inhibitor.

Fractionation of histones. The salt-extracted histones were fractionated into $\mathrm{H} 2 \mathrm{~A}-\mathrm{H} 2 \mathrm{~B}$ and $\mathrm{H} 3-\mathrm{H} 4$ complexes (24) on a $5 \times 110-\mathrm{cm}$ Sephadex G-100 (Pharmacia Fine Chemicals, Div. of Pharmacia Inc., Piscataway, N. J.) column equilibrated in $50 \mathrm{mM} \mathrm{Na}$ acetate buffer, $\mathrm{pH} 5.0$, and $50 \mathrm{mM} \mathrm{NaHSO}$. A $50-\mathrm{mg}$ sample in $5 \mathrm{ml}$ of $20 \%$ sucrose (wt/vol) was applied to the column in the running buffer and eluted at a flow rate of $15 \mathrm{ml} / \mathrm{h} .10-\mathrm{ml}$ fractions were collected and absorbance read at $230 \mathrm{~nm}$ on a spectrophotometer. The peaks were pooled and concentrated by Millipore ultrafiltration to $1 \mathrm{mg} / \mathrm{ml}$ and stored in $0.5-\mathrm{ml}$ aliquots at $-70^{\circ} \mathrm{C}$ until further use. The concentration of histone was determined by the extinction coefficient at $230 \mathrm{~nm}$ (A230) reported by others (25) of $A 230=3.3$ for $\mathrm{H} 2 \mathrm{~A}-\mathrm{H} 2 \mathrm{~B}$. The extinction coefficient of $\mathrm{Hl}$ was taken to be 1.85. Purity of the histone preparations was monitored by the A230/A260 where a ratio of at least 6 was taken as criterion for pure histone preparations (26). In practice, our histone preparations had an A230/A260 of 10.

Analysis of histone. Histones were analyzed by acid-urea polyacrylamide gel electrophoresis as described by Panyim and Chalkley (27). Histone samples were dissolved in $0.9 \mathrm{~N}$ acetic acid containing $20 \%$ sucrose (wt/vol) and left at $4^{\circ} \mathrm{C}$ overnight before application to gels. Gels $(9 \mathrm{~mm} \times 15 \mathrm{~cm})$ were cast at a final acrylamide concentration of $15 \%$ containing $6.25 \mathrm{M}$ urea. After application of the sample, the gels were electrophoresed for $4 \mathrm{~h}$ at $2 \mathrm{~mA} / \mathrm{gel}$; stained overnight in $40 \%$ acetic acid and $7 \%$ ethanol containing $1 \%$ amido black. Gels were destained in a commercial destaining apparatus containing $40 \%$ acetic acid. Commercially prepared H1 (Worthington Biochemical Corp., Freehold, N. J.) was added in each gel $1 \mathrm{~h}$ before the termination of electrophoresis. This served as a control to show that histone proteins were able to penetrate the acid-urea polyacrylamide gel and as a marker protein to align different gels for comparison.

\section{RESULTS}

Immunofluorescent studies with antinuclear antibodies. The usual antinuclear antibody fluorescent pattern produced by drug-induced LE sera is shown in Fig. 1 $a$. This pattern can be described as homogeneous/ patchy with nuclear rim stain. After tissue sections were extracted with $0.1 \mathrm{~N} \mathrm{HCl}$, the same serum showed no nuclear staining (Fig. $1 b$ ). When acid-extracted tissue sections were reconstituted with nuclear histones, this serum again became positive for nuclear fluorescence. The nuclear staining was distinctly clumpy with clumps of different sizes present in each nucleus. As will be discussed later, the majority of drug-induced LE demonstrated these characteristics. Other than nuclear stain-

FIGURE 1 The effect of extraction with $0.1 \mathrm{~N} \mathrm{HCl}$ when mouse kidney sections were used as substrate for the detection of antinuclear antibodies in the sera of a patient with drug-induced LE. (a) Control-untreated section showing homogenous pattern of staining at a serum dilution of $\mathrm{y}_{16}$. (b) Section extracted with $0.1 \mathrm{~N} \mathrm{HCl}$, then used as substrate for ANA determination. There was no nuclear staining even when serum was used at dilution of $1 / 2$. . (c) Section extracted, reconstituted with histone, and used as substrate for ANA. There was restoration of nuclear fluorescence in a clumped pattern at all serum dilutions tested (from $1 / 2$ to $1 / 64$ ). 
ing, only one patient (treated with procainamide) in the drug-LE group had cytoplasmic staining. In contrast, idiopathic SLE sera behaved differently. On untreated tissue sections, SLE sera gave variable patterns of nuclear staining including homogeneous/patchy, rim, and speckled. This is consistent with many reported studies and is known to be related to antibodies reacting with different nuclear antigens (19). It was of interest that none of the 23 drug-induced LE sera demonstrated speckled patterns of nuclear fluorescence. On acidextracted and histone-reconstituted sections, idiopathic SLE sera showed great variability as reported below.

Histochemical studies. Because sera of some patients with idiopathic SLE had positive nuclear fluorescence after acid extraction, the nature of the unextracted nuclear antigens was examined histochemically by the alkaline fast green FCF technique and the acridine orange technique (Table I). The acridine orange staining of untreated sections produced green nuclei, an indication that the dye was intercalated into doublestranded (ds)DNA (27). After extraction of nuclei with $0.1 \mathrm{~N} \mathrm{HCl}$, the green staining of the nuclei was retained indicating the continued presence of dsDNA. Alkaline fast green FCF, which reacts with nuclear histone, stained untreated sections to give green nuclei. After acid extraction, there was complete loss of nuclear staining, whereas a positive fast green FCF staining of nuclei was again seen after reconstitution with saltextracted histones. After treatment with deoxyribonuclease (DNase 1, Worthington Biochemical Corp., 40 $\mu \mathrm{g} / \mathrm{ml}$ in PBS; $3 \mathrm{mM} \mathrm{MgCl}$ for $60 \mathrm{~min}$ at $37^{\circ} \mathrm{C}$ ), there was no acridine orange staining of the nuclei in any of the tissues, indicating loss of dsDNA. DNase treatment of tissues did not affect staining with alkaline fast green in the tissues where histones had been demonstrated to be present (control sections and histone-reconstituted

\section{TABLE I}

Histochemical Characterization of Mouse Kidney Sections Used for the Immunofluorescent Demonstration of Anti-Histone Antibodies

\begin{tabular}{|c|c|c|c|c|c|c|}
\hline & \multicolumn{2}{|c|}{$\begin{array}{l}\text { Control sections } \\
\text { treated with }\end{array}$} & \multicolumn{2}{|c|}{$\begin{array}{l}\text { Acid-extracted } \\
\text { sections treated } \\
\text { with }\end{array}$} & \multicolumn{2}{|c|}{$\begin{array}{c}\text { Histone- } \\
\text { reconstituted } \\
\text { sections treated } \\
\text { with }\end{array}$} \\
\hline & PBS & DNase* $^{*}$ & PBS & DNase $^{*}$ & PBS & DNase* \\
\hline \multicolumn{7}{|l|}{ Acridine } \\
\hline orange $\neq$ & + & - & + & - & + & - \\
\hline Alkaline & & & & & & \\
\hline green $\oint$ & + & + & - & - & + & + \\
\hline
\end{tabular}

* DNase treatment as described in text.

\$ Histochemical stain for DNA (Methods). + indicates positive staining of dsDNA.

$\$$ Histochemical stain for histone (Methods). + indicates positive staining of histone. sections). Thus, by histochemical techniques, it could be ascertained that after acid extraction, dsDNA could still be demonstrated in nuclei but not histones. Not shown in the table was the further observation that residual DNA in acid-extracted tissues was essential for histone reconstituion because prior treatment of extracted tissues with DNase prevented the reconstitution of histones to nuclei.

Histone antibodies in drug-induced and idiopathic LE sera. The prevalence of antibodies to histones was determined in drug-induced LE and idiopathic SLE by utilizing acid-extracted and histone-reconstituted tissue sections. On untreated tissue sections, the mean ANA titer of the drug-induced LE group was 1:234, and the mean ANA of the idiopathic SLE group was 1:294. The range of ANA was $1: 16$ to $1: 1,024$ for the drug-induced group and $1: 64$ to $1: 1,024$ for the idiopathic SLE group. In the study shown in Fig. 2, the ANA titers of each serum were determined on untreated, acid-extracted, and histone-reconstituted tissue. In the drug-induced LE group, all 23 sera completely lost nuclear staining on acid-extracted tissues. On histone-reconstituted tissues, 22 of the 23 sera regained nuclear staining, the majority with titers within one dilution of the titers on untreated tissue sections. Only one serum failed to regain nuclear staining on histone-reconstituted tissue. The findings with the idiopathic SLE sera were significantly different. Only 12 of 20 sera were negative for ANA on acid-extracted tissues. Of the remaining eight sera, four showed a decrease in ANA titer and four showed no change. Of the

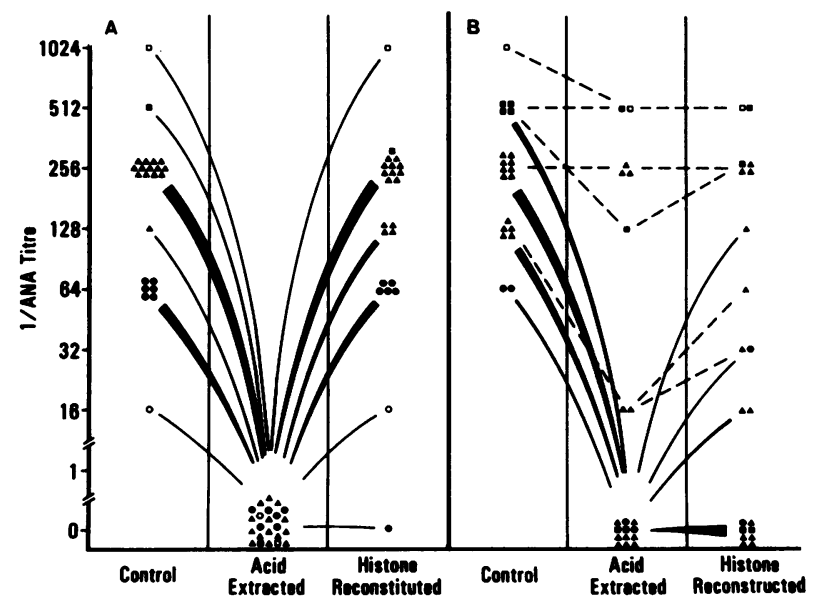

FIgURE 2 The prevalence of antibodies to histones was examined on control-untreated tissue sections, acid-extracted tissues, and histone-reconstituted tissues. (A) In drug-induced LE, all sera became negative for ANA on acid-extracted tissues and 22 of 23 regained ANA titers on histone-reconstituted tissues. (B) In contrast, idiopathic SLE sera showed variable patterns, some were negative on acid-extracted tissues, whereas others were not. Many did not regain ANA titers on histone-reconstituted tissues. (See text). 
12 sera that had negative ANA on extracted tissues, only 4 regained nuclear staining on histone-reconstituted tissues, and the other 8 continued to be negative for nuclear staining. It will be shown subsequently that the latter sera were those which contained antibody to nonhistone nuclear proteins. Of the four sera which showed a decrease in ANA titer on acid-extracted tissues, three demonstrated an increase in titer on reconstituted sections. Thus, a total of $7 / 20$ idiopathic SLE sera might be considered to have antibodies to histones.

Specificity of sera reacting with histones. Histones were separated into three fractions. $\mathrm{H} 1$ was obtained by differential extraction of chromatin with $0.6 \mathrm{M} \mathrm{NaCl}$ followed by purification on Sephadex G-100. The other histones are extracted by $2.0 \mathrm{M} \mathrm{NaCl}$ and then separated into H2A-H2B and H3-H4 complexes by Sephadex G-100 gel filtration (Fig. 3A). H2A-H2B were not crosscontaminated with $\mathrm{H} 3-\mathrm{H} 4$ and vice versa as judged by polyacrylamide gel electrophoresis (Fig. $3 \mathrm{~B}$ ) and were found to be free of significant DNA contamination because the A230/A260 ratios were found to be $>6$.

These purified histone fractions were then used for reconstitution experiments. Of the 22 drug-induced LE sera that had reconstituted with total histone, 21 showed reconstitution with the H2A-H2B complexes (Table II). Three of these sera also showed reactivity with $\mathrm{H} 3-\mathrm{H} 4$ and two of these three showed reactivity with $\mathrm{Hl}$.

Of the five idiopathic SLE sera that had increased or regained ANA titers with total histone reconstitution, three showed reactivity with $\mathrm{H} 2 \mathrm{~A}-\mathrm{H} 2 \mathrm{~B}$, and two showed reactivity with $\mathrm{Hl}$, and of the three sera reacting with $\mathrm{H} 2 \mathrm{~A}-\mathrm{H} 2 \mathrm{~B}$, one showed reactivity with $\mathrm{H} 3-\mathrm{H} 4$ at low serum dilutions (Table II). We have attempted to de-

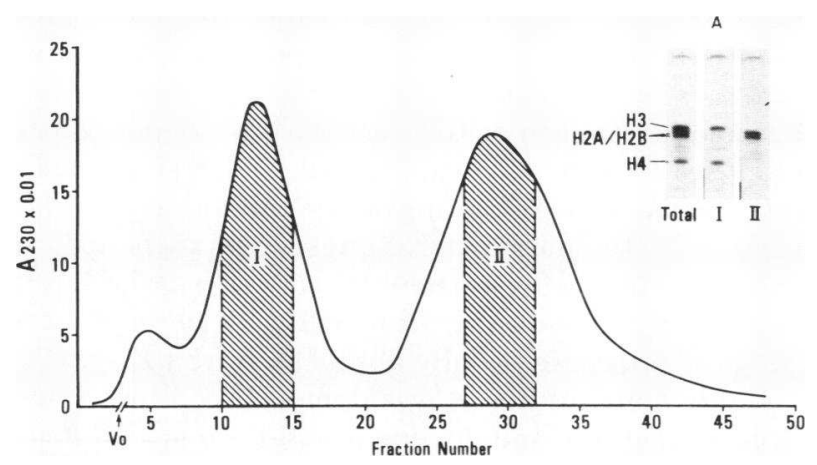

FIGURE 3 Gel filtration on Sephadex G-100 of salt-extracted calf thymus histones $\mathrm{H} 2 \mathrm{~A}, \mathrm{H} 2 \mathrm{~B}, \mathrm{H} 3$, and H4. Samples were dissolved in $50 \mathrm{mM}$ sodium acetate, $\mathrm{pH} 5.0 ; 50 \mathrm{mM}$ sodium bisulfate; and $20 \%$ sucrose; and applied to the column. Column dimensions, $5.0 \times 110 \mathrm{~cm}$; sample weight, $50 \mathrm{mg}$; sample volume, $5.0 \mathrm{ml}$; and fraction volume, $10 \mathrm{ml}$. Polyacrylamide electrophoresis of the samples representative of the shaded areas of peaks I and II are shown in (A). The H3-H4 complexes are resolved from the H2A-H2B complexes by this technique.
TABLE II

Comparison of Reactivity of Lupus Sera with Histone Fractions

\begin{tabular}{lccccc}
\hline & \multicolumn{4}{c}{ Number of sera reactive with } \\
\cline { 2 - 5 } & $\begin{array}{c}\text { Total } \\
\text { histones }\end{array}$ & H1 & H2A-H2B & H3-H4 \\
\hline Idiopathic SLE & 5 & 2 & 3 & 1 \\
Drug LE & 22 & 2 & 21 & 3 \\
\hline
\end{tabular}

termine if antibodies to histones could be detected by the immunodiffusion technique, using commercial histones and our own purified histone fractions. This method was found to be unreliable because nonspecific precipitin reactions occurred frequently. One cause for this was found to be due to traces of DNA present in some SLE sera which produced precipitin lines when they were adjacent to wells containing histone.

Nonhistone antibody profiles. The antibody profiles of the drug-induced LE sera (Table III) included three with antibodies to single-stranded DNA, but sera with antibodies to nonhistone proteins $\mathrm{Sm}$, nuclear ribonucleoprotein, or Sjögren's syndrome antigen B were not detected. The antibody profiles of the idiopathic SLE group were found to be much more complex. Sera with antibodies to dsDNA were found to be those which continued to show nuclear staining on acidextracted tissues. Sera with antibodies to $\mathrm{Sm}$, ribonucleoprotein, Sjögren's syndrome antigen B (syndrome antigen $B$ ), and without coexisting anti-dsDNA, were negative for nuclear staining on acid-extracted

TABLE III

Antibody Profile of Drug-Induced LE and Idiopathic SLE Correlated with Immunofuorescence Reaction on Acid Extracted Mouse Kidney Sections

\begin{tabular}{lccccc}
\hline & Total & $\begin{array}{c}\text { Anti- } \\
\text { Sm }\end{array}$ & $\begin{array}{c}\text { Anti- } \\
\text { RNP" }\end{array}$ & $\begin{array}{c}\text { Anti- } \\
\text { dsDNA }\end{array}$ & $\begin{array}{r}\text { Anti- } \\
\text { ssDNA }\end{array}$ \\
\hline $\begin{array}{l}\text { Idiopathic SLE } \\
\text { Complete loss of }\end{array}$ & & & & & \\
$\quad$ ANA* & 12 & 7 & 2 & 0 & 3 \\
$\quad \begin{array}{l}\text { Partial loss of } \\
\quad \text { ANA }\end{array}$ & 4 & 2 & 1 & 3 & 2 \\
$\quad \begin{array}{l}\text { No loss of ANA } \$ \\
\text { Drug LE }\end{array}$ & 4 & 0 & 0 & 4 & 0 \\
$\quad \begin{array}{c}\text { Complete loss of } \\
\text { ANA* }\end{array}$ & 23 & 0 & 0 & 0 & 3 \\
\hline
\end{tabular}

Abbreviations used: RNP, ribonucleoprotein; ssDNA, singlestranded DNA.

* Complete loss of ANA on acid-extracted tissues.

$\$$ Decrease in ANA titer of at least one doubling dilution on acid-extracted tissues.

$\S$ No change in ANA titer on acid-extracted tissues.

"Determined by Ouchterlony immunodiffusion.

I Determined by Millipore filter radioimmunoassay. 
tissues and remained negative on histone-reconstituted sections. This was related to the observation that acidtreatment also eluted nonhistone proteins from nuclei (1).

\section{DISCUSSION}

Autoantibodies to nuclear antigens have been the subject of increasing interest recently, but most investigations have been directed toward autoantibodies to nucleic acids and to nonhistone proteins of the nucleus. One of the earliest studies on autoantibodies to histones was performed with the complement-fixation method (2). In this study, a few sera from patients with systemic lupus erythematosus were identified which contained antibodies towards calf thymus total histones. It was believed that autoantibodies to histones were present in relatively few sera from patients with systemic lupus erythematosus. Investigations along this line were extended by Stollar (3) and associates with a micro-complement fixation method. These investigators studied SLE sera especially selected for the presence of antibodies to histones. They showed that the majority of sera also contained antibodies to histone fractions $2 \mathrm{~A}, 2 \mathrm{~B}, 3$, and 4 . In the present report where a limited number of idiopathic SLE sera were studied, 7 of 20 sera contained antibodies to histones. Thus, the frequency of anti-histone antibodies in this group of SLE patients was $35 \%$. In contrast, antibodies to histones were present in 22 of $23(96 \%)$ of patients with drug-induced LE.

The majority of antibodies to histones in drug-induced LE were directed against histone fractions $2 \mathrm{~A}$ and $2 \mathrm{~B}$. In addition, we observed that no antibodies to native DNA were present in drug-induced LE sera and no antibodies were detected against nonhistone protein antigens such as $\mathrm{Sm}$ and nuclear ribonucleoprotein. The latter finding is also consistent with the recent report of Winfield et al. (28) who reported that patients on long-term therapy with procainamide had a very low incidence of antibodies to nonhistone nuclear acidic protein antigens. This is in contrast to patients who had just been started on therapy with procainamide, in some of whom antibodies to nuclear acidic protein antigens could be detected within 3 days after initiation of therapy.

Some investigators have reported that histones at higher concentration are anticomplementary (4). The immunofluorescent method circumvents the problem of the anti-complementary feature of histones. The sensitivity of the immunofluorescent method is as good as the complement-fixation method. In idiopathic SLE and drug-induced LE, titers of antibodies to histones often reached $1 / 256$ and $1 / 512$. In reported studies with the complement-fixation method, titers were generally in the range of $1 / 100(3)$. We have observed that com- mercially available histone preparations can be used for immunofluorescent studies, so that it may not be necessary to prepare more highly purified histone preparations unless more careful studies concerning antibodies to specific histone subfractions are required.

Questions have been raised previously concerning the antigenic determinant which reacts with antibodies to either DNP or histones. Previous investigations by Stollar (3) have shown that there are antibodies which react with DNA-histone complex. In work previously reported (1), we showed that other basic proteins such as protamine, poly-L-lysine, and poly-L-arginine were not able to substitute for histones as the reactive antigenic determinants in our immunofluorescent technique. Thus, requirement for histones as part of the antigenic determinant was clearly established. With our immunofluorescent technique, however, the DNA remaining in the cell nucleus after acid elution of other proteins was an essential component for histone reconstitution. If the DNA was removed by DNase digestion, histone could no longer be reconstituted on the acidtreated tissue sections. At the present time, we have no direct evidence for one of two possibilities concerning the precise chemical nature of the antigenic determinant reactive with antibodies to histones. The first possibility is that histones themselves possess the complete antigenic determinant and that DNA provided the necessary "scaffolding" for the unfolding and presentation of this antigenic site. The second possibility is that histones complex with DNA to create a new junctional determinant which is the antigenic site.

In practice, we have found that the immunofluorescent method for determination of autoantibody to histones has been a valuable help in the differential diagnosis between idiopathic SLE and drug-induced LE. Because of the absence of antibodies to native DNA in drug-induced LE, a previously positive ANA serum becomes totally negative on acid-eluted sections and becomes strongly positive again on histone-reconstituted sections. In contrast, idiopathic SLE sera usually retain some nuclear staining on acid-eluted sections because of antibodies to DNA present in such sera. In addition, other analysis should reveal autoantibodies to nonhistone protein antigens in SLE sera whereas these autoantibodies are usually absent in drug LE sera.

In previous studies, it was demonstrated that a possible mechanism for induction of anti-histone antibodies in drug-induced LE might be due to the capacity of drugs, such as hydralazine, to form physicochemical bonds with DNA-histone (7). The drug-nucleoprotein complex protects the histone portion of the nucleoprotein from digestion with trypsin. It was postulated that in vivo such a drug-histone complex might protect histones from proteolytic breakdown and preserve histone in immunogenic form. No experiments with procainamide have been performed to demonstrate that 
this drug has the same property as hydralazine, but because antibodies to histones appear to be a common feature of drug-induced LE syndromes, it is possible that a common mechanism for induction of anti-histone antibodies occurs in all these diseases.

\section{ACKNOWLEDGMENTS}

This paper was supported by National Institutes of Health grant AM 21356 and by a grant from the Kroc Foundation for the Advancement of Medical Science.

\section{REFERENCES}

1. Tan, E. M., J. Robinson, and P. Robitaille. 1976. Studies of antibodies to histones by immunofluorescence. Scand. J. Immunol. 5: 89-96.

2. Kunkel, H. G., H. R. Holman, H. R. G. Deicher. 1960. Multiple "autoantibodies" to cell constituents in systemic lupus erythematosus. Ciba Found. Symp. 8: 429-437.

3. Stollar, B. D. 1971. Reactions of systemic lupus erythematosus sera with histone fractions and histone-DNA complexes. Arthritis Rheum. 14: 485-492.

4. Hekman, A., and M. Sluyser. 1973. Antigenic determinants on lysine-rich histones. Biochim. Biophys. Acta. 295: $613-620$.

5. Holman, H. R., H. R. Deicher. 1959. The reaction of lupus erythematosus (LE) cell factor with deoxyribonucleoprotein of the cell nucleus. J. Clin. Invest. 38: 2059-2072.

6. Tan, E. M. 1967. An immunologic precipitin system between soluble nucleoprotein and serum antibody in systemic lupus erythematosus. J. Clin. Invest. 46: 735-745.

7. Tan, E. M. 1974. Drug-induced autoimmune disease. Fed. Proc. 33: 1894-1897.

8. Perry, H. M., Jr., E. M. Tan, S. Carmody, and A. Sakamoto. 1970. Relationship of acetyl transferase activity to antinuclear antibodies and toxic symptoms in hypertensive patients treated with hydralazine. J. Lab. Clin. Med. 176: $114-125$.

9. Woosley, R. L., A. S. Nies, D. Drayer, M. Reidenberg, and J. A. Oates. 1977. Acetylator phenotype as a factor in procainamide-induced lupus erythematosus. Clin. Res. 25: 299A. (Abstr.)

10. Hnilica, L. S. 1975. Methods for analysis of histones. Methods Enzymol. 40: 102-138.

11. Ohlenbusch. H. H., B. M. Olivera, D. Tuan, and N. Davidson. 1967. Selective dissociation of histones from calf thymus nucleoprotein. J. Mol. Biol. 25: 299-315.

12. Kornberg, R. D., and J. O. Thomas. 1974. Chromatin structure: oligomers of the histones. Science (Wash. D. C.). 184: 865-868.

13. Mihalakis, N., O. J. Miller, and B. F. Erlanger. 1976. Anti- bodies to histones and histone-histone complexes: immunochemical evidence for secondary structure in histone I. Science (Wash. D. C.). 192: 469-471.

14. Cohen, A. S., W. E. Reynold, E. C. Franklin. J. P. Kulka, M. W. Ropes, L. E. Shulman, and S. L. Wallace. 1971. Preliminary criteria for the classification of systemic lupus erythematosus. Bull. Rheum. Dis. 21: 643-648.

15. Northway, J. D., and E. M. Tan. 1972. Differentiation of anti-nuclear antibodies giving speckled staining patterns in immunofluorescence. Clin. Immunol. Immunopathol. 1: 140-154.

16. Alspaugh, M. A., and E. M. Tan. 1975. Antibodies to cellular antigens in Sjögren's Syndrome. J. Clin. Invest. 55: 1067-1076.

17. Ginsberg, B., and H. Keiser. 1973. A Millipore filter assay for antibodies to native DNA in sera of patients with systemic lupus erythematosus. Arthritis Rheum. 16: 199207.

18. Picazo, J. J., and E. M. Tan. 1975. Specificities of antibodies to native DNA. Scand. J. Rheumatol. (Suppl. II): 35-41.

19. Tan, E. M. 1967. Relationship of nuclear staining pattern with precipitating antibodies in systemic lupus erythematosus. J. Lab. Clin. Med. 70: 800-812.

20. Frommhagen, L. 1965. The solubility and other physiochemical properties of human gamma globulin labelled with fluorescein isothiocyanate.J. Immunol. 95: 442-445.

21. Berkowitz, L., D. Palotta, and P. Pawlowski. 1970. Isolated histone fractions and the alkaline fast green reaction. $J$. Histochem. Cytochem. 18: 334-339.

22. Bertalanffy, L. von, and I. Bickis. 1956. Identification of cytoplasmic basophilia (ribonucleic acid) by fluorescence microscopy. J. Histochem. Cytochem. 4: 481-493.

23. Allfrey, V. G., V. C. Littau, and A. E. Mirsky. 1964. Methods for the purification of thymus muclei and their application to studies of nuclear protein synthesis. J. Cell. Biol. 21: 213-234.

24. Van Der Westhuyzen, D. R., and C. von Holt. 1971. A new procedure for the isolation and fractionation of histones. FEBS (Fed. Eur. Biochem. Soc.) Lett. 14: 333-337.

25. Camerini-Otero, R. D., B. Sollner-Webb, and G. Felsenfeld. 1976. The organization of histones and DNA in chromatin: evidence for an arginine-rich histone kernel. Cell. 8: 333-347.

26. Weintraub, H., K. Palter, and F. Van Lente. 1975. Histones $\mathrm{H} 2 \mathrm{~A}, \mathrm{H} 2 \mathrm{~B}, \mathrm{H} 3$ and $\mathrm{H} 4$ form a tetrameric complex in solutions of high salt. Cell. 6: 85-110.

27. Panyim, S., and R. Chalkley. 1969. High resolution acrylamide gel electrophoresis of histones. Arch. Biochem. Biophys. 130: 337-346.

28. Winfield, J. B., D. Koffler, and H. G. Kunkel. 1975. Development of antibodies to ribonucleoprotein following short-term therapy with procainamide. Arthritis Rheum. 18: $531-534$. 